\title{
Influence of Austenitizing on the Mechanical Properties of Maraging 300 and Sae 4340 Steels - Comparative Study
}

\author{
Sérgio Souto Maior Tavares ${ }^{a, b *}$, Juan Manuel Pardal ${ }^{a}$, Tabatta Regina de Brito Martins ${ }^{c}$, Vanessa \\ Milhomem Schmitt ${ }^{d}$, Jorge Felipe Veiga Szlejf ${ }^{\prime}$ \\ ${ }^{a}$ Universidade Federal Fluminense, Rua Passo da Pátria $n^{\circ} 156$,Niterói-RJ, 24210-240, Brazil \\ ${ }^{b}$ Programa de Pós-graduação em Engenharia de Materiais, Centro Federal de Educação Tecnológica \\ Celso Suckow da Fonseca - CEFET-RJ, Brazil \\ c Programa de Engenharia de Nanotecnologia, Universidade Federal do Rio de Janeiro, Av. Horácio \\ Macedo, 2030 - Centro de Tecnologia; Ilha do Fundão-RJ, 21945-970, Brazil \\ ${ }^{d}$ Centro Federal de Educação Tecnológica Celso Suckow da Fonseca, Unidade Itaguai, Rodovia Mário \\ Covas, lote J2, quadra J, Itaguai-RJ, 23810-000, Brazil
}

Received: November 28, 2016; Revised: March 08, 2017; Accepted: April 05, 2017.

\begin{abstract}
Maraging steels with $18 \mathrm{wt} \% \mathrm{Ni}$ and $10 \mathrm{wt} \% \mathrm{Co}$ are precipitation hardenable steels selected for special applications. These steels are quenched and aged in the $480-600^{\circ} \mathrm{C}$ range. Ti and Mo are added to precipitate during aging as fine $\mathrm{Ni}_{3}(\mathrm{Ti}, \mathrm{Mo})$ and $\mathrm{Fe}_{2}$ Mo particles. Aging at high temperatures causes overaging due to coarsening of particles and austenite formation. SAE 4340 is a typical low alloy medium carbon steel for quenching and tempering. The best combination of mechanical properties is attained by quenching and tempering in the $650-670^{\circ} \mathrm{C}$ range. These two steels are selected for services where an optimum combination of mechanical strength, toughness and fatigue resistance is required. In this work, the austenitizing temperature in the quenching treatment was varied in order to evaluate the effects on microstructure and mechanical properties of both steels. The results showed that the effect of previous austenite grain size on the toughness was different in the two steels analyzed.
\end{abstract}

Keywords: maraging 300 steel; SAE 4340 steel; quenching and tempering; previous austenite grain size.

\section{Introduction}

The influence of grain size on the mechanical properties of metallic materials, specifically in steels, has been extensively studied over the years. It is well known the strengthening effect (Hall Petch relation) and the increase of toughness by grain refinement ${ }^{1}$.

The grain size of quenched and tempered (Q\&T) steels is that of the previous austenite phase. This grain size is function of the austenitization temperature and time $\mathrm{e}^{2-4}$. In Q\&T low alloy steels, such as SAE 4340, 4140, 8640 and others, the austenitizing temperature range for commercial heat treatments must be high enough to homogenize the austenite, but low enough to avoid the austenite grain coarsening. Excessively coarse previous austenite grain size may promote intergranular quenching cracks in this family of steels ${ }^{5}$. Other effect of the coarse austenite grain size in low alloy Q\&T steels is the increase of retained austenite, as observed in SAE 4340 steel $^{3}$.

Maraging steels are solution treated (or quenched) and aged in temperatures in the range of $450^{\circ} \mathrm{C}$ to $650^{\circ} \mathrm{C}$ depending on the microstructure and properties desired for the final product ${ }^{6-7}$. The low carbon martensite produced by

* e-mail: ssmtavares@terra.com.br solution treatment is soft and has high toughness. The aging reactions produce a strong strengthening attributed to the precipitation of fine $\mathrm{Ni}_{3}(\mathrm{Ti}, \mathrm{Mo})$ and $\mathrm{Fe}_{2} \mathrm{Mo} \mathrm{particles}^{7-8}$. The peak of hardness is attained with aging temperatures around $480^{\circ} \mathrm{C}$. Aging at high temperatures, above $500^{\circ} \mathrm{C}$, causes coarsening of particles and austenite formation, which make the hardness decrease (overaging).

Maraging 300 and 350 steels may be substitutes for Q\&T SAE 4340 steel, and virse-vers $a^{9}$. In the present work, the effect of austenitizing temperature on the microstructure and mechanical properties of a maraging steel class 300 and a low alloy medium carbon steel SAE 4340 were studied and compared.

\section{Materials and experimental methods}

The chemical compositions of a class 300 maraging steel and a SAE 4340 low alloy steel are shown in Table 1. Maraging was from a $11 \mathrm{~mm}$ plate cut from a forged cylinder with $250 \mathrm{~mm}$ of diameter, and the SAE 4340 steel was from hot rolled and normalized bar with $16 \mathrm{~mm}$ of diameter.

The maraging plate was cut and machined for approximate dimensions of Charpy specimens $\left(57 \times 11 \times 11 \mathrm{~mm}^{3}\right)$ and tensile specimens. These specimens were heat treated by solution 
Table 1. Chemical composition of maraging 300 and SAE 4340 steels.

\begin{tabular}{lccccccccccc}
\hline Elements & $\mathrm{Ni}$ & $\mathrm{Co}$ & $\mathrm{Mo}$ & $\mathrm{Al}$ & $\mathrm{Cr}$ & $\mathrm{Si}$ & $\mathrm{Ti}$ & $\mathrm{C}$ & $\mathrm{Mn}$ & $\mathrm{P}$ & $\mathrm{S}$ \\
\hline Maraging & 18.33 & 9.400 & 5.00 & 0.106 & 0.110 & 0.040 & 0.790 & 0.007 & 0.020 & $<0.005$ & $<0.001$ \\
SAE 4340 & 1.781 & --- & 0.221 & --- & 0.739 & 0.348 & --- & 0.413 & 0.687 & 0.029 & 0.030 \\
\hline
\end{tabular}

treatment and aging following the parameters indicated in Table 2. Two solution treatment temperatures were used to obtain different austenitic grain sizes: $1150^{\circ} \mathrm{C}$ (coarse grain$\mathrm{CG}$ ) and $820^{\circ} \mathrm{C}$ (fine grain-FG). After solution treatment the specimens were aged to different levels of strength.

Table 2. Heat treatments parameters applied to maraging steel.

\begin{tabular}{lcc}
\hline Solution treatment & Aging & $\begin{array}{c}\text { Specimen } \\
\text { identification }\end{array}$ \\
\hline & un-aged & FG \\
Soaking: $820^{\circ} \mathrm{C} / 1 \mathrm{~h}$ & $480^{\circ} \mathrm{C} / 1 \mathrm{~h}$ & FG-480-3 \\
Oil quenching & $600^{\circ} \mathrm{C} / 1 \mathrm{~h}$ & FG-600-1 \\
& $600^{\circ} \mathrm{C} / 4 \mathrm{~h}$ & FG-600-4 \\
\hline & un-aged & $\mathrm{CG}$ \\
Soaking: $1150^{\circ} \mathrm{C} / 1 \mathrm{~h}$ & $480^{\circ} \mathrm{C} / 1 \mathrm{~h}$ & $\mathrm{CG}-480-3$ \\
Oil quenching & $600^{\circ} \mathrm{C} / 1 \mathrm{~h}$ & $\mathrm{CG}-600-1$ \\
& $600^{\circ} \mathrm{C} / 4 \mathrm{~h}$ & $\mathrm{CG}-600-4$ \\
\hline
\end{tabular}

SAE 4340 steel was also cut and machined to approximate dimensions of Charpy and tensile specimens before heat treatments. The specimens were then quenched and tempered or double tempered, as defined in Table 3. Two austenitizing temperatures were tested $\left(860^{\circ} \mathrm{C}\right.$ and $\left.1060^{\circ} \mathrm{C}\right)$ in order to obtain different previous austenite grain sizes.

After the heat treatments, the Charpy specimens were machined to the final dimensions $\left(55 \times 10 \times 10 \mathrm{~mm}^{3}\right)$ with $\mathrm{V}$-notch. The tensile specimens were grinded with emery paper grit 400 and 600 to remove oxidation layer.

The austenitic grain sizes of both the quenched SAE 4340 and the solution treated maraging 300 steels were measured by quantitative metallography with specimens mechanically polished and etched. The etching for SAE 4340 steel was a solution with $100 \mathrm{ml} \mathrm{H}_{2} \mathrm{O}, 4 \mathrm{~g}$ of picric acid and $4 \mathrm{~g}$ of $\mathrm{FeCl}_{3}$. This etching is applied with cotton, alternating the application of detergent with glycerin and the etching solution for 3

Table 3. Heat treatments parameters applied to SAE 4340 steel.

\begin{tabular}{lcc}
\hline Quenching & Tempering & $\begin{array}{c}\text { Specimen } \\
\text { identification }\end{array}$ \\
\hline un-tempered & Q860 \\
Soaking: $860^{\circ} \mathrm{C} / 1 \mathrm{~h}$ & $650^{\circ} \mathrm{C} / 1 \mathrm{~h}$ & Q860-T650 \\
Oil quenching & $650^{\circ} \mathrm{C} / 1 \mathrm{~h}+$ & Q860-DT650 \\
& $650^{\circ} \mathrm{C} / 1 \mathrm{~h}$ & \\
un-tempered & Q1060 \\
Soaking: $1060^{\circ} \mathrm{C} / 1 \mathrm{~h}$ & $650^{\circ} \mathrm{C} / 1 \mathrm{~h}$ & Q1060-T650 \\
Oil quenching & $650^{\circ} \mathrm{C} / 1 \mathrm{~h}+$ & Q1060-DT650 \\
& $650^{\circ} \mathrm{C} / 1 \mathrm{~h}$ & \\
\hline
\end{tabular}

or 4 times. The maraging steel was electrolytically etched with a $10 \% \mathrm{Cr}_{2} \mathrm{O}_{3}$ solution, applying a voltage of $30 \mathrm{~V}$. The grain sizes were measured by the intercept method as per ASTM E-112 10 .

For the general martensitic structure, both CG and FG specimens of maraging solution treated were etched with Marble's solution $\left(10 \mathrm{~g} \mathrm{CuSO}_{4}, 50 \mathrm{ml} \mathrm{HCl}\right.$ and $50 \mathrm{ml} \mathrm{H}_{2} \mathrm{O}$ ) and SAE 4340 was etched with nital $2 \%$.

Magnetic measurements in a Vibrating Sample Magnetometer (VSM) were performed to detect and quantify austenite in the various heat treatment conditions. Specimens with the geometry of small discs of $3.0 \mathrm{~mm}$ of diameter were used to obtain the magnetization curve $M$ versus $H$, were $M$ is the magnetization and $\mathrm{H}$ is the magnetic field applied to the sample. The magnetization saturation $\left(\mathrm{m}_{\mathrm{s}}\right)$ was determined by extrapolation of the magnetization $\mathrm{x} 1 / \mathrm{H}$ for $1 / \mathrm{H} \rightarrow 0$, as shown in Figure 1. The austenite volume fractions were calculated using the linear relations:

$$
\begin{gathered}
C_{M}+C_{\gamma}=1 \\
C_{M}=\frac{m_{s}}{m_{s(i)}}
\end{gathered}
$$

where $\mathrm{C}_{\mathrm{M}}$ and $\mathrm{C} \gamma$ are the volume fractions of martensite and austenite respectively; $\mathrm{m}_{\mathrm{s}}$ is the magnetization saturation of the specimen; and $\mathrm{m}_{\mathrm{s}(\mathrm{i})}$ is the magnetization saturation of a specimen with $100 \%$ of martensite, which was produced by quenching and low temperature tempering (SAE 4340) or aging (maraging). For this reason, specimens of SAE 4340 quenched at $860^{\circ} \mathrm{C}$ and tempered in the $200-500^{\circ} \mathrm{C}$ and specimens of maraging steel solution treated and aged at $300^{\circ} \mathrm{C}$ and $400^{\circ} \mathrm{C}$ were specially produced to be tested in the VSM and determinate the $\mathrm{m}_{\mathrm{S}(\mathrm{i})}$ for each material.

Tensile tests and Charpy impact tests with V-notched specimens were performed at room temperature. Fracture surfaces were observed in the scanning electron microscope after the Charpy tests. Three specimens per heat treatment condition were tensile tested and impact tested. The average values will be presented.

\section{Results and discussion}

\subsection{Steel SAE4340}

Figures 2(a-b) and 3(a-b) compare the microstructures of SAE 4340 quenched from $860^{\circ} \mathrm{C}$ and $1060^{\circ} \mathrm{C}$, respectively. In Figures 2(a) and 3(a) the previous austenitic grain boundaries were revealed by etching with the picric acid 


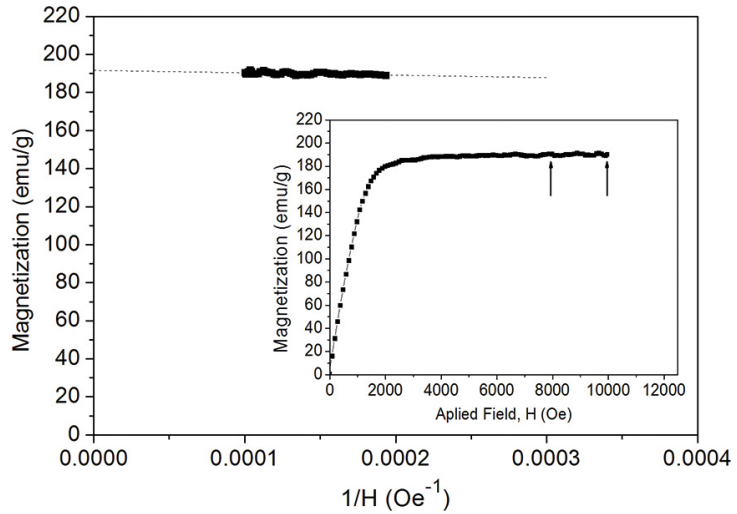

Figure 1. Magnetization curve and curve of $\mathrm{M} x 1 / \mathrm{H}$ of specimen maraging GG. Determination of $\mathrm{mS}$. 286x201 mm (150 x $150 \mathrm{DPI})$

and $\mathrm{FeCl}_{3}$ solution described. The average austenite grain sizes of specimens quenched from $860^{\circ} \mathrm{C}$ and $1060^{\circ} \mathrm{C}$ were $8.3 \pm 1.3 \mu \mathrm{m}$ (ASTM 10.5) and 14.2 $\pm 0.9 \mu \mathrm{m}$ (ASMT 9.0), respectively.

Low alloy martensite, also known as massive or lath martensite, is characterized by packets, while high alloy martensite is acicular, with plates. In the case of SAE 4340 a mixed structure is expected. Comparing Figures 2(a) and 2(b), it can be inferred that the increase of the austenitic grain size favors the acicular morphology of the martensite.

Table 4 shows the hardness, the magnetic results and the amount of retained austenite in as quenched SAE 4340 steel. The $\mathrm{m}_{\mathrm{S}(\mathrm{i})}$ value adopted was $219.2 \mathrm{emu} / \mathrm{g}$, which corresponds to the specimen quenched at $860^{\circ} \mathrm{C}$ and tempered at $400^{\circ} \mathrm{C}$. The increase of austenitic grain size increases the retained austenite volume fraction. Also, the hardness decreases with the increase of retained austenite.

Table 5 shows the tensile properties of specimens of SAE 4340 quenched as well as quenched and tempered. Specimens quenched from $860^{\circ} \mathrm{C}$ and tempered at $650^{\circ} \mathrm{C}$ show higher ductility, but slightly lower yield and tensile strengths than specimens quenched from $1060^{\circ} \mathrm{C}$. For both quenching temperatures $\left(860^{\circ} \mathrm{C}\right.$ and $\left.1060^{\circ} \mathrm{C}\right)$ the double tempering caused an increase of mechanical resistance, but little effect on ductility was observed.

Table 6 shows the impact Charpy results of specimens quenched and quenched and tempered. The quenching from $860^{\circ} \mathrm{C}$ resulted in higher toughness and the double

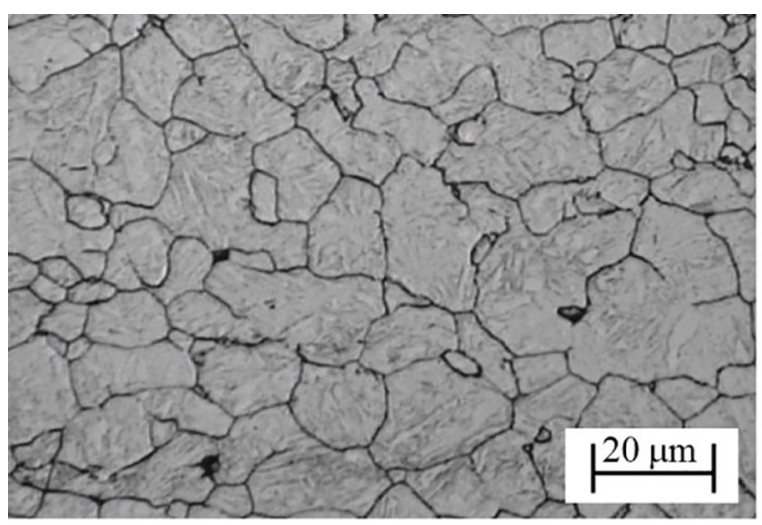

(a)

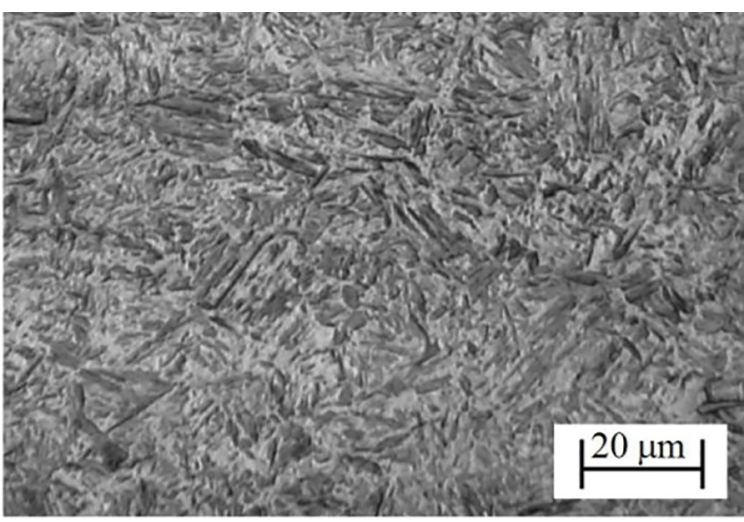

(b)

Figure 2. Microstructure of specimen of SAE 4340 Q860: (a) Previous austenite grains; (b) general martenstic microstructure.

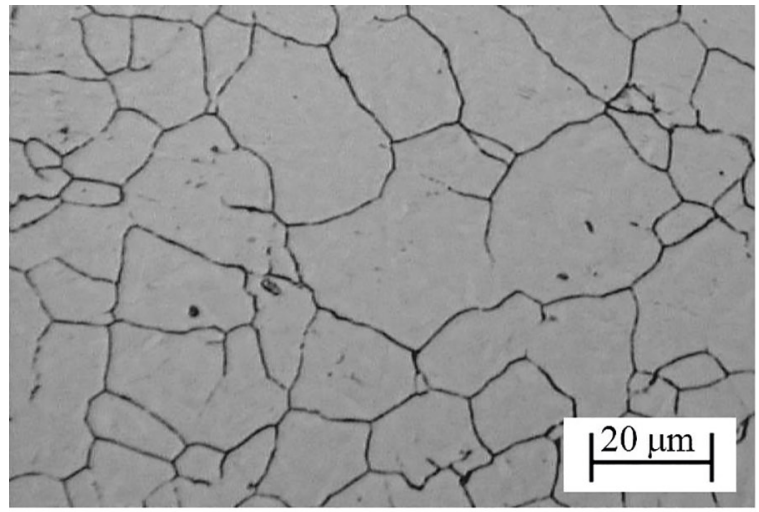

(a)

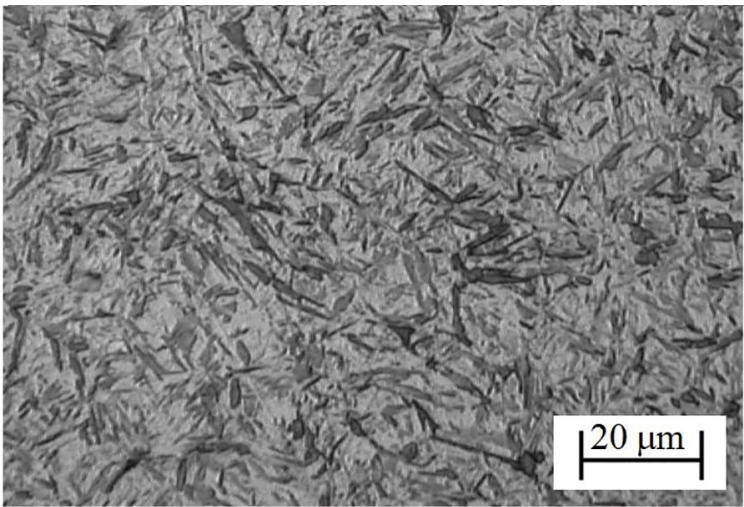

(b)

Figure 3. Microstructure of specimen of SAE 4340 Q1060: (a) Previous austenite grains; (b) general martensitic microstructure. 
Table 4. Magnetic measurement of austenite volume fraction $\left(\mathrm{C}_{\gamma}\right)$ and hardness HV10 of specimens of SAE 4340 quenched from $860^{\circ} \mathrm{C}$ and $1060^{\circ} \mathrm{C}$.

\begin{tabular}{lccc}
\hline Specimen & $\mathrm{m}_{\mathrm{S}(\mathrm{i})}(\mathrm{emu} / \mathrm{g})$ & $\mathrm{C} \gamma$ & HV10 \\
\hline Q860 & 206.5 & 5.8 & $750 \pm 30$ \\
Q1060 & 179.5 & 18.1 & $630 \pm 25$ \\
\hline
\end{tabular}

Table 5. Tensile properties of SAE 4340 steel. (average values).

\begin{tabular}{lcccc}
\hline Specimen & $\begin{array}{c}\text { Yield } \\
\text { strength } \\
(\mathrm{MPa})\end{array}$ & $\begin{array}{c}\text { Ultimate } \\
\text { Strength } \\
(\mathrm{MPa})\end{array}$ & $\begin{array}{c}\text { Elongation } \\
(\%)\end{array}$ & $\begin{array}{c}\text { Area } \\
\text { reduction } \\
(\%)\end{array}$ \\
\hline Q860-T650 & 793 & 890 & 16.1 & 76.2 \\
Q860-DT650 & 866 & 945 & 15.8 & 60.4 \\
Q1060-T650 & 810 & 924 & 12.4 & 49.1 \\
Q1060-DT650 & 931 & 995 & 12.1 & 50.2 \\
\hline
\end{tabular}

tempered also increased the impact energy. Figure 4 shows a comparison of the surface of fracture of specimens Q860 and Q860-DT650. The quenched material has an aspect of quasi-cleavage, while the specimen quenched and tempered at $650^{\circ} \mathrm{C}$ shows ductile fracture with dimples nucleated at non-metallic inclusions.

Figures 5(a-b) and 6(a-b) compare the microstructures of maraging $\mathrm{FG}$ and $\mathrm{CG}$, as solution treated. The average grain size of FG and CG were $58.4 \pm 1.8 \mu \mathrm{m}$ (ASTM 5.0) and $247.9 \pm 0.5 \mu \mathrm{m}$ (ASTM 0.7), respectively.

Table 7 shows the magnetic results and the quantification of austenite in maraging steel. The low temperature aging did not increase the $m_{S}$, which suggests that the solution treated specimens did not contain retained austenite, or its volume fraction was insignificant, for both solution treatment temperatures. The $\mathrm{m}_{\mathrm{S}(\mathrm{i})}$ was that of specimen solution treated at $820^{\circ} \mathrm{C}(\mathrm{FG}), 191.1 \mathrm{emu} / \mathrm{g}$, which is very close to the $\mathrm{m}_{\mathrm{s}}$ of the specimen $\mathrm{CG}\left(1150^{\circ} \mathrm{C}\right)$. Differently from the low alloy SAE 4340, the increase of the austenite grain size did not increase the volume fraction of retained austenite in the solution treated specimens.

Austenite phase appears when maraging steels are aged at high temperatures, typically above $500^{\circ} \mathrm{C}^{8}$. Specimens aged at $600^{\circ} \mathrm{C}$ show volume fractions of the so called reverse austenite increasing with aging time. However, from the comparison of specimens FG-600-1 and CG-600-1 in table 7, it seems clear that the lower the austenitic grain size the higher is the initial kinetics of reverse austenite precipitation. Specimens aged at $600^{\circ} \mathrm{C}$ for $4 \mathrm{~h}$ show similar amounts of austenite.
Table 8 shows the tensile properties and hardness, while Table 9 exhibits the impact Charpy results of maraging steel. Differently from the SAE 4340 low alloy steel, the higher toughness in the maraging 300 steel is obtained in the as-quenched condition, and that of coarse grained material was superior to the fine grained steel. The impact toughness increased from 80 $\mathrm{J}$ to $145 \mathrm{~J}$ with the increase of austenitic grain size from $58.4 \pm$ $1.8 \mu \mathrm{m}$ (ASTM 5.0) to $247.9 \pm 0.5 \mu \mathrm{m}$ (ASTM 0.7).

When the maraging steel is aged to the peak of hardness $\left(480^{\circ} \mathrm{C}-3 \mathrm{~h}\right)$ the toughness was very low. Furthermore, the aging at $600^{\circ} \mathrm{C}$ for $1 \mathrm{~h}$ also produced a very brittle microstructure, and, the increase of aging time to $4 \mathrm{~h}$, which increased the austenite content, caused a further decrease of toughness in $\mathrm{CG}$ and FG. It can be concluded that, under the conditions established in this work, reverse austenite does not improve the toughness of maraging 300 steel.

The grain coarse material presents both lower hardness and mechanical strength when aged at $480^{\circ} \mathrm{C}$. As a consequence, the properties of maraging 300 (UTS $\geq 2094 \mathrm{MPa}$ ) are achieved only in the fine grained material.

Other works have investigated the effect of grain size on mechanical properties of maraging $18 \% \mathrm{Ni}$ steels ${ }^{11-13}$. Saul et al. ${ }^{11}$ observed the increase of room temperature tensile strength with grain refinement of austenite, in agreement to results presented here. Also, Sinha et al. ${ }^{12}$ observed the increase of fracture toughness of solution treated specimens with the increase of austenitizing temperature and, consequently, austenitic grain size. On the other hand, $\operatorname{Rack}^{13}$ reported that the prior austenite grain size did not affect the fracture toughness of unaged $18 \mathrm{Ni}$ maraging steel.

Figures 7(a), (b) and (c) show the surface fractures of specimens CG, CG-480-3 and CG-600-4. Solution treated specimen (CG) has large microvoids (dimples), while the brittle fractures of maraging 300 CG-480-3 and CG-600-4 are manly characterized by very small dimples. Portions of cleavage or quasi-cleavage were rarely observed in these brittle fractures. The decrease of dimples size indicates embrittlement. Hilders and Santana ${ }^{14}$ proposed an inverse relation between the fracture toughness and the square root of the average dimple diameter.

\subsection{Comparison between SAE 4340 and maraging 300 steel}

The maximum hardness and mechanical resistance of SAE4340 is obtained in the as-quenched condition, but the

Table 6. Impact properties of SAE 4340 steel.

\begin{tabular}{lccccc}
\hline Specimen & Energy $(\mathrm{J})$ & $\begin{array}{c}\text { Lateral expansion } \\
(\mathrm{mm})\end{array}$ & Specimen & Energy $(\mathrm{J})$ & $\begin{array}{c}\text { Lateral expansion } \\
(\mathrm{mm})\end{array}$ \\
\hline Q860 & 7.5 & 0 & Q1060 & 3.2 & 0 \\
Q860-T650 & 91.0 & 1.05 & Q1060-T650 & 86.0 & 0.70 \\
Q860-DT650 & 98.5 & 1.88 & Q1060-DT650 & 94.5 & 1.42 \\
\hline
\end{tabular}




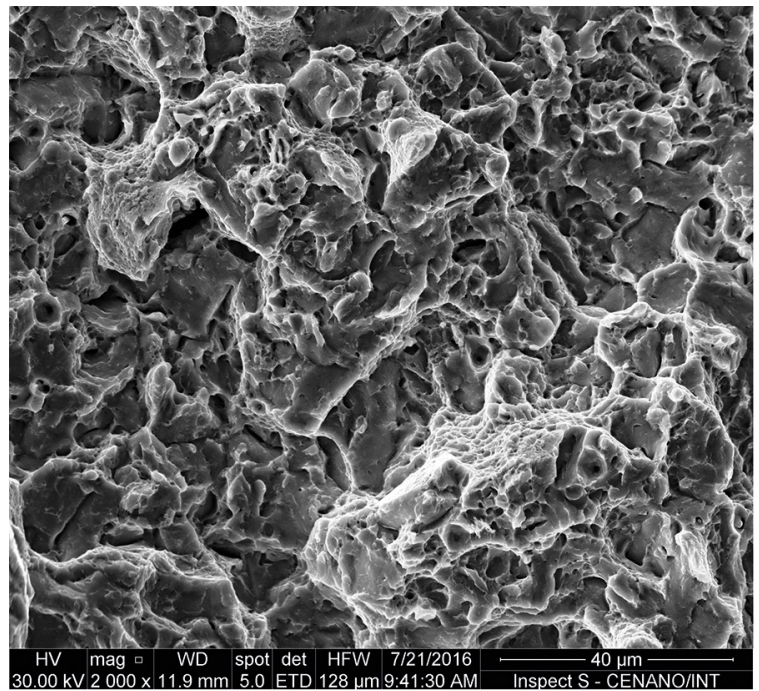

(a)

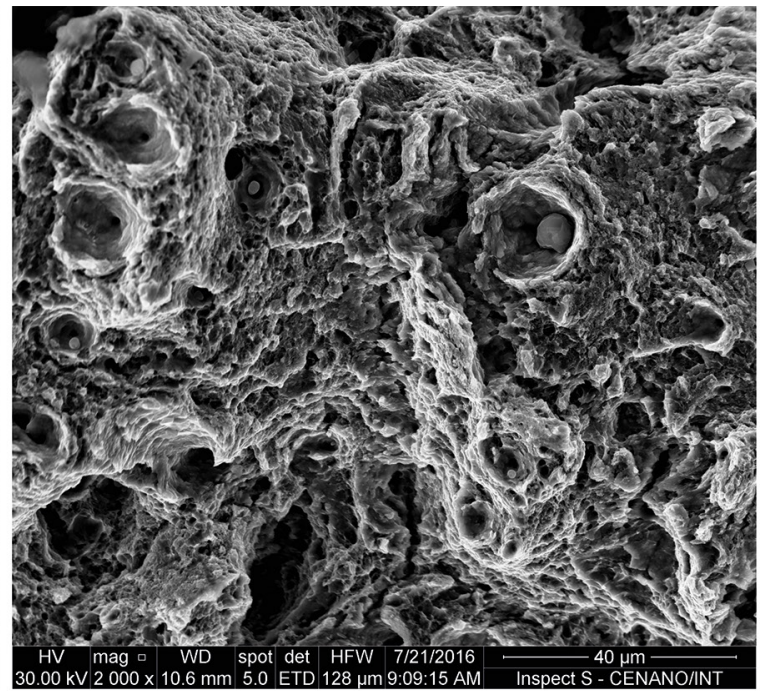

(b)

Figure 4. Fracture surface of specimens (a) Q860 and (b) Q860-T650.
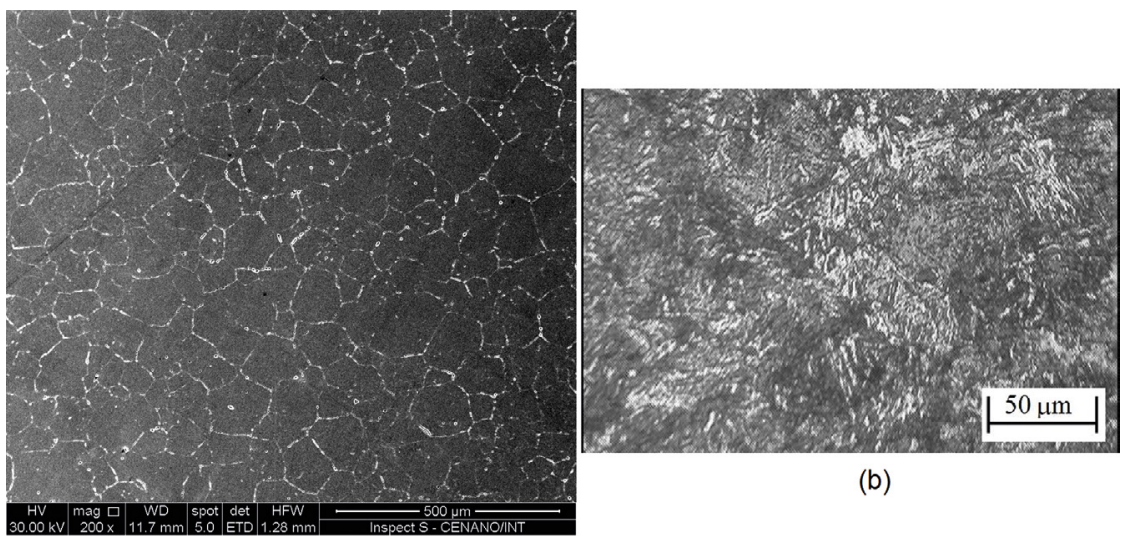

(b)

(a)

Figure 5. Microstructure of maraging 300 FG: (a) etching for previous austenite; (b) Marble's etching.

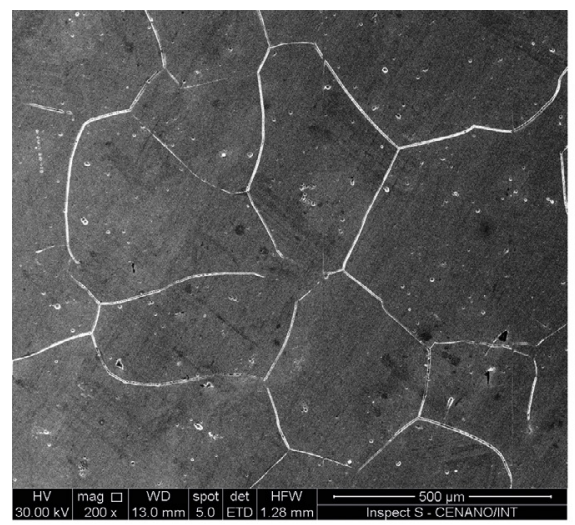

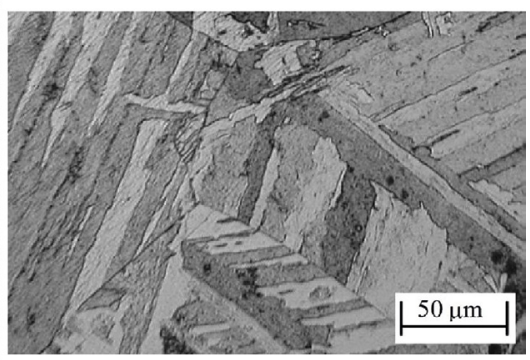

(b)

(a)

Figure 6. Microstructure of maraging 300 CG: (a) etching for previous austenite; (b) Marble's etching. 
Table 7. Magnetic measurement of austenite volume fraction $\left(\mathrm{C}_{\gamma}\right)$ of specimens of maraging 300 .

\begin{tabular}{lcccc}
\hline Specimen & \multicolumn{2}{c}{$\mathrm{FG}$} & \multicolumn{2}{c}{$\mathrm{CG}$} \\
& $\begin{array}{c}\mathrm{m}_{\mathrm{S}(\mathrm{i})} \\
(\mathrm{emu} / \mathrm{g})\end{array}$ & $\mathrm{C}_{\gamma}$ & $\begin{array}{c}\mathrm{m}_{\mathrm{S}(\mathrm{i})} \\
(\mathrm{emu} / \mathrm{g})\end{array}$ & $\mathrm{C} \gamma$ \\
\hline $\begin{array}{l}\text { Solution treated }- \\
\text { Un-aged }\end{array}$ & 191.1 & $<0.010$ & 190.6 & $<0.010$ \\
$300^{\circ} \mathrm{C} / 1 \mathrm{~h}$ & 190.4 & $<0.010$ & 189.2 & $<0.010$ \\
$480^{\circ} \mathrm{C} / 3 \mathrm{~h}$ & 191.4 & $<0.010$ & 191.7 & $<0.010$ \\
$600^{\circ} \mathrm{C} / 1 \mathrm{~h}$ & 169.4 & 0.115 & 180.8 & 0.055 \\
$600^{\circ} \mathrm{C} / 4 \mathrm{~h}$ & 145.2 & 0.241 & 148.0 & 0.227 \\
\hline
\end{tabular}

Table 8. Tensile properties (YS = Yield strength, UTS=Ultimate Tensile Strength, El. = Elongation, $\mathrm{RA}=$ Reduction of area) and Vickers Hardness of maraging steel specimens.

\begin{tabular}{llllll}
\hline Specimen & $\begin{array}{l}\text { YS } \\
\text { (MPa) }\end{array}$ & $\begin{array}{l}\text { UTS } \\
(\mathrm{MPa})\end{array}$ & El. (\%) & RA (\%) & (HV30) \\
\hline FG & 1028 & 1105 & 14.2 & 70.6 & $328 \pm 4$ \\
FG-480-3 & 2119 & 2125 & 4.9 & 24.3 & $593 \pm 11$ \\
FG-600-4 & 1380 & 1454 & 10.0 & 38.8 & $475 \pm 3$ \\
CG & 928 & 1002 & 14.3 & 76.4 & $318 \pm 3$ \\
CG-480-3 & 1764 & 1777 & 4.3 & 16.8 & $575 \pm 5$ \\
CG-600-4 & 1452 & 1577 & 5.3 & 27.8 & $490 \pm 8$ \\
\hline
\end{tabular}

Table 9. Impact Charpy tests results of maraging 300.

\begin{tabular}{cccccc}
\hline \multicolumn{2}{c}{ FG } & \multicolumn{5}{c}{ CG } \\
Specimen & $\begin{array}{c}\text { Energy } \\
(\mathrm{J})\end{array}$ & $\begin{array}{c}\text { Lat. } \\
\text { Exp. } \\
(\mathrm{mm})\end{array}$ & Specimen & $\begin{array}{c}\text { Energy } \\
(\mathrm{J})\end{array}$ & $\begin{array}{c}\text { Lat. } \\
\text { Exp. } \\
(\mathrm{mm})\end{array}$ \\
\hline FG & 80 & 0.6 & CG & 145 & 1.5 \\
FG-480-3 & 16 & 0.2 & CG-480-3 & 13 & 0.2 \\
FG-600-1 & 16 & 0.1 & CG-600-1 & 16 & 0.1 \\
FG-600-4 & 14 & 0.1 & CG-600-4 & 13 & 0.1 \\
\hline
\end{tabular}

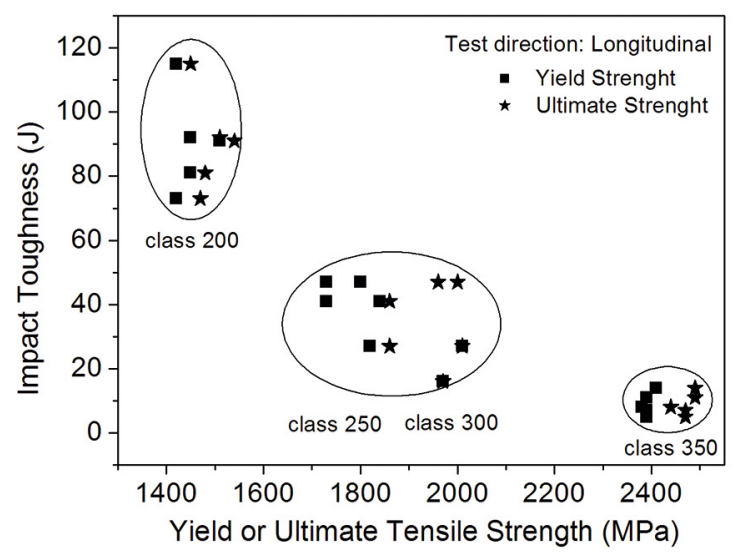

(a) toughness is too low and stress level is too high for any application in this heat treatment condition. Tempering between $400-600^{\circ} \mathrm{C}$ promotes temper embrittlement ${ }^{15}$, which can be mitigated but not eliminated by the decrease of impurities levels. The optimization of mechanical properties of this steel is obtained with quenching and tempering in 600$670^{\circ} \mathrm{C}$ range. Double tempering promotes a small increase of toughness. On the other hand, austenitizing temperatures as high as $1060^{\circ} \mathrm{C}$ are not recommended because the risk of quench cracks.

Maraging steels show a typical inverse relation between toughness and mechanical resistance. The increase of strength level promotes the decrease of impact toughness, as shown in Figure 8 constructed with the data reported in by the Nickel Development Institute ${ }^{16}$. However, in the as solution treated condition maraging steels have excellent toughness with hardness and tensile properties comparable to SAE 4340 quenched and tempered or double tempered at $650^{\circ} \mathrm{C}$.

Fig. 9 compares the engineering tensile curves of maraging $300 \mathrm{CG}$ and SAE 4340 Q860-DT650, respectively. Table 10 compares the mechanical properties of the two steels (maraging 300 and SAE 4340) in the conditions in which they show higher toughness. Analyzing the options of Table $10,18 \mathrm{Ni}$ maraging steel solution treated with high austenitizing temperature shows the best mechanical properties, although SAE 4340 has higher uniform elongation than maraging CG steel.

\section{Summary and conclusions}

A comparison between a maraging steel $18 \% \mathrm{Ni}-10 \% \mathrm{Co}$ class 300 and a SAE 4340 steel considering different heat treatment conditions in each steel was conducted in this work.

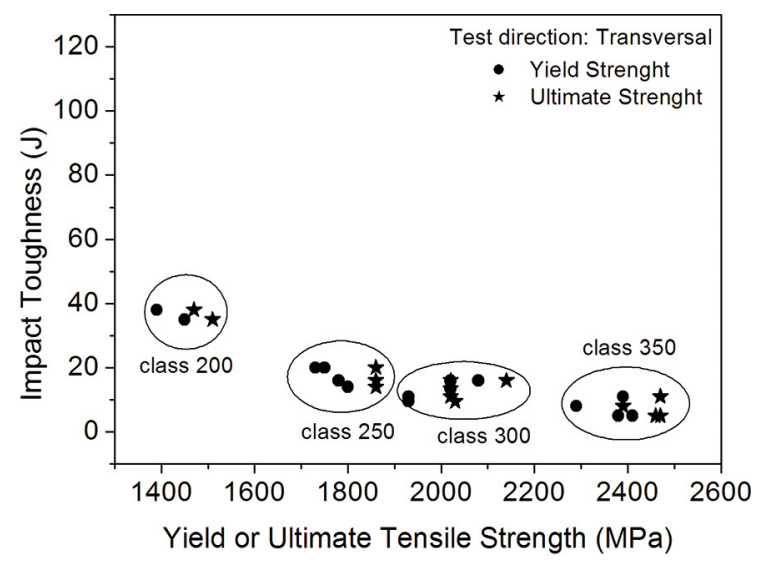

(b)

Figure 7. Surface of fracture of specimens (a) CG, (b) CG-480-3 and (c) CG-600-4 (same magnification). 


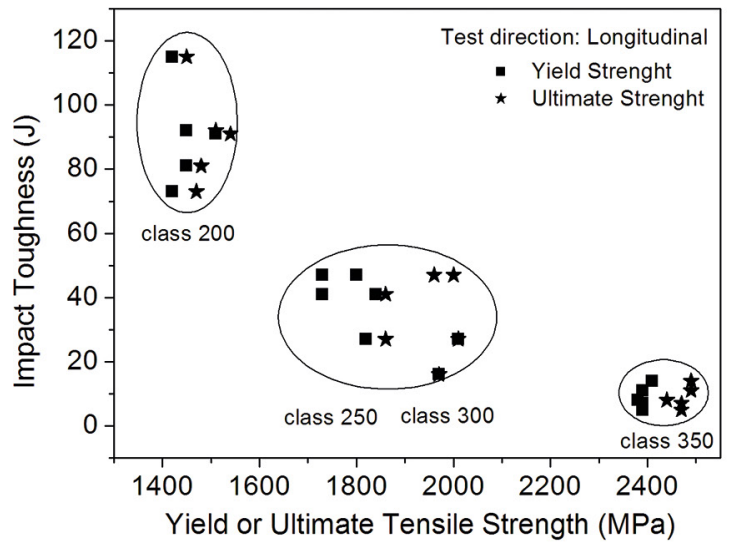

(a)

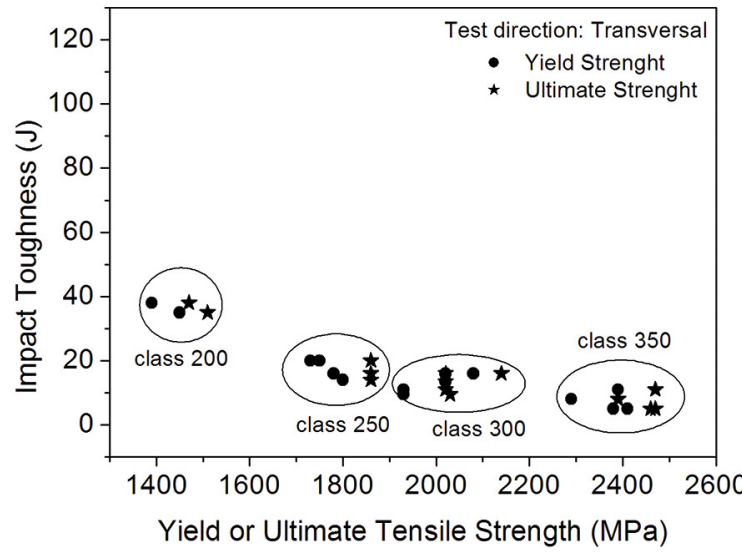

(b)

Figure 8. Impact toughness and yield/ultimate strength of maraging 200, 350, 300 and 35016: (a) longitudinal and (b) transversal direction.

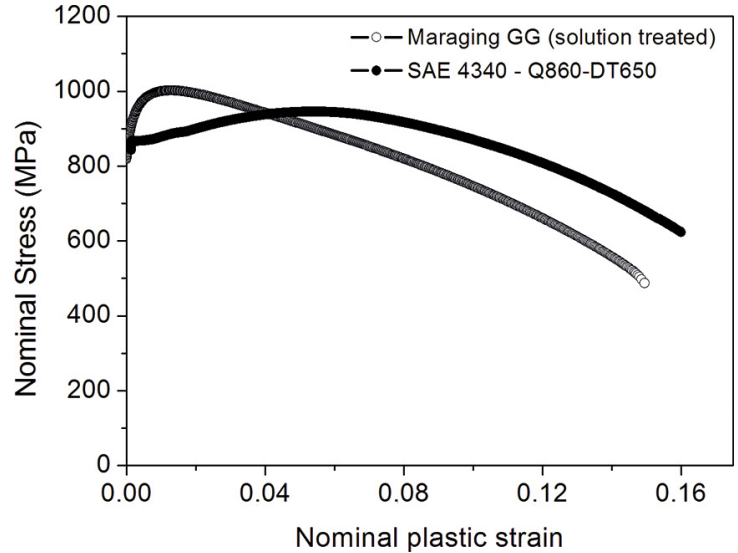

Figure 9. Nominal stress versus nominal strain curves of maraging CG (un-aged) and SAE 4340 Q-860-DT650.

- The increase of the previous austenitic grain size ASTM 5.0 to ASTM 0.7 by raising the solution treatment temperature from $820^{\circ} \mathrm{C}$ to $1150^{\circ} \mathrm{C}$ increased the toughness of maraging steel in the un-aged (solution treated) condition. However, in the SAE 4340 steel the opposite and more expected behavior was observed, i.e. the reduction of the previous austenite grain size from ASMT 9.0 to ASTM 10.5 improved the toughness of quenched as well as quenched and tempered specimens.

- After aging at $480^{\circ} \mathrm{C} / 3 \mathrm{~h}$ or $600^{\circ} \mathrm{C} / 1 \mathrm{~h}$ and $4 \mathrm{~h}$ the maraging steel becomes brittle, with little difference between the specimens with coarse and fine previous austenitic grain.

- $\quad$ The properties of maraging $300\left(\sigma_{\mathrm{UTS}} \geq 2094 \mathrm{MPa}\right)$ were achieved in the material solution treated at $820^{\circ} \mathrm{C}$ (fine austenitic grain), but not in the material solution treated at $1150^{\circ} \mathrm{C}$ (coarse austenitic grain), i.e., the refinement of the austenite grain promoted some strengthening of the martensite aged and un-aged.

- Despite of the reverse austenite formation on aging $18 \mathrm{Ni}$ maraging steel at $600^{\circ} \mathrm{C}$ for $1 \mathrm{~h}$ and $4 \mathrm{~h}$, and the decrease of hardness, the Charpy impact toughness was as low as that of material aged at $480^{\circ} \mathrm{C}$ to the peak of hardness. This result suggests that reverse austenite does not improve the toughness of $18 \mathrm{Ni}$ maraging steels.

- The brittle fracture surface of maraging steel specimens solution treated and aged at $480^{\circ} \mathrm{C}$ for $3 \mathrm{~h}$ was characterized by dimples much smaller than the un-aged specimen. Similar behavior was observed in the specimens aged at $600^{\circ} \mathrm{C}$ for $4 \mathrm{~h}$. The surface of fracture of quenched SAE 4340 steel has an aspect of quasi-cleavage, while the specimen quenched and tempered at $650^{\circ} \mathrm{C}$ shows ductile fracture with dimples nucleated at nonmetallic inclusions.

- The increase of the austenitic grain size increased the amount of retained austenite in SAE 4340. In $18 \mathrm{Ni}$ maraging steel, the increase of grain size

Table 10. Comparison between maraging 300 and SAE 4340 processed for high toughness.

\begin{tabular}{lccccc}
\hline Steel/condition & YS $(\mathrm{MPa})$ & UTS $(\mathrm{MPa})$ & El. $(\%)$ & RA $(\%)$ & \multicolumn{2}{c}{ Impact energy $(\mathrm{J})$} \\
\hline Maraging CG & 928 & 1002 & 14.3 & 76.4 & 145 \\
Maraging FG & 1028 & 1105 & 14.2 & 70.6 & 80 \\
4340 860-650 & 793 & 890 & 16.1 & 76.2 & 91.0 \\
4340 860-D650 & 866 & 945 & 15.8 & 60.4 & 98.5 \\
\hline
\end{tabular}


did not cause the retention of austenite in solution treatment. On the other hand, the initial kinetics of austenite formation at $600^{\circ} \mathrm{C}$ was higher in the specimen with finer austenitic grain.

\section{Acknowledgements}

Authors acknowledge the Brazilian Research Agencies CNPq (Grant 305294/2014-8) and FAPERJ (E-26/203033/2015) for financial support.

\section{References}

1. Calcagnotto M, Ponge D, Raabe D. Effect of grain refinement to $1 \mu \mathrm{m}$ on strength and toughness of dual-phase steels. Materials Science and Engineering: A. 2010;527(29-30):7832-7840.

2. Yang K, Qu WS, Kong FY, Su GY. Effects of solution treatment temperature on grain growth and mechanical properties of high strength $18 \% \mathrm{Ni}$ cobalt free maraging steel. Materials Science and Technology. 2003;19(1):117-124.

3. Ajus C, Tavares SSM, da Silva MR, Corte RRA. Magnetic properties and retained austenite quantification in SAE 4340 steel. Revista Matéria. 2009;14(3):993-999.

4. Sinha PP, Sreekumar K, Natarajan A, Nagarajan KV. Grain growth in 18Ni 1800MPa maraging steel. Journal of Materials Science. 1991;26(15):4155-4159.

5. ASM International. ASM Handbook: volume 4: Heat Treating. Materials Park: ASM International; 1991.

6. Wang G, Yan Y, Li J, Qiao L, Volinsky AA. Microstructure effect on hydrogen-induced cracking in TM210 maraging steel. Materials Science and Engineering: A. 2013;586:142-148.

7. Viswanathan UK, Dey GK, Asundi MK. Precipitation hardening in 350 grade maraging steel. Metallurgical Transactions A. 1993;24(11):2429-2442.
8. Tewari R, Mazumder S, Batra IS, Dey GK, Banerjee S. Precipitation in $18 \mathrm{wt} \% \mathrm{Ni}$ maraging steel of grade 350. Acta Materialia. 2000;48(5):1187-1200.

9. Cardoso ASM, Abdala AJ, de Lima MSF, Bonjorni FM, Barboza MJR, Bapstista CARP, et al. Study of Laser Welding and Heat Treatments Done in Different High Strength Steels: 4340, 300M, Maraging 300. In: $22^{\text {nd }}$ SAE Brasil International Congress and Display; 2013; São Paulo, SP, Brazil.

10. ASTM International. ASTM E112 - 13 - Standard Test Methods for Determining Average Grain Size. West Conshohocken: ASTM International; 2013.

11. Saul G, Roberson JA, Adair AM. The effects of thermal treatment and austenitic grain size and mechanical properties of $18 \mathrm{pct}$ Ni maraging steels. Metallurgical and Materials Transactions B. 1970;1(2):383-387.

12. Sinha PP, Sreekumar K, Babu NS, Pant B, Natarajan A, Nagarajan KV. Development of heat treatment parameters to improve fracture toughness and grain size of an embrittled maraging steel. Journal of Heat Treating. 1992;9(2):125-131.

13. Rack HJ. The role of prior austenite grain size on the tensile ductility and fracture toughness of $18 \mathrm{Ni}$ maraging steels. Scripta Metallurgica. 1979;13(7):577-582.

14. Hilders OA, Santana MG. Toughness and fractography and austenitic type 304 stainless steel with sensitization treatments at 973K. Metallography. 1988;21(2):151-164.

15. Materkowski JP, Krauss G. Tempered martensite embrittlement in SAE 4340 steel. Metallurgical Transactions A. 1979;10(11):16431651.

16. Nickel Development Institute. 18\%Ni Maraging Steels. Engineering Properties. $1^{\text {st }}$ Ed. London: INCO Europe; 1976. p. 3-12. 


\section{Erratum}

In the article "Influence of Austenitizing on the Mechanical Properties of Maraging 300 and Sae 4340 Steels - Comparative Study", DOI number: http://dx.doi.org/10.1590/1980-5373-MR-2016-0884, published in Mat. Res. in May 02, 2017, in the page 6 where was written:

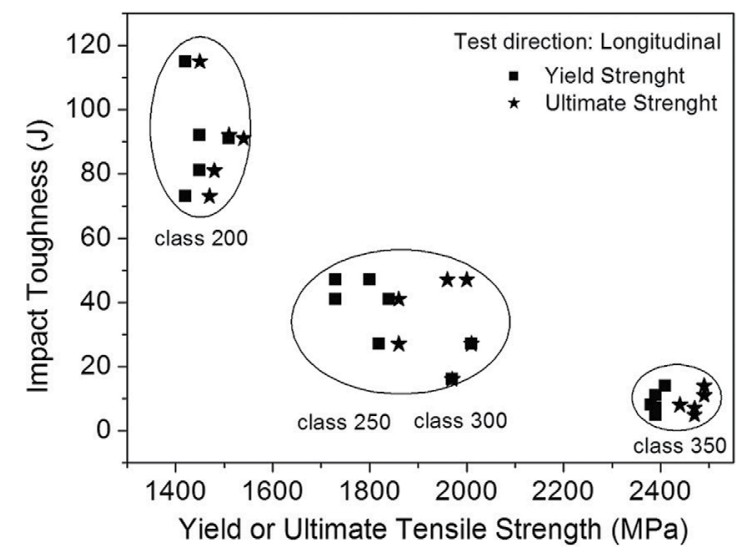

(a)

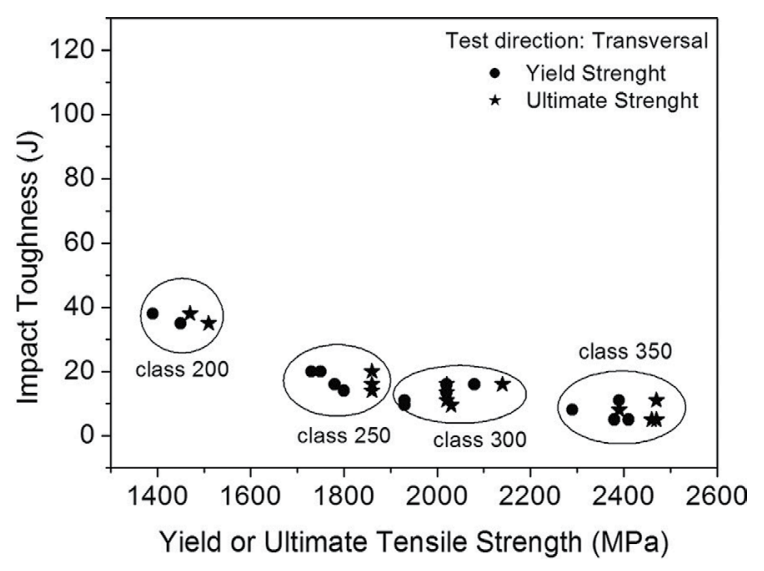

(b)

Figure 7. Surface of fracture of specimens (a) CG, (b) CG-480-3 and (c) CG-600-4 (same magnification)

It should be read:

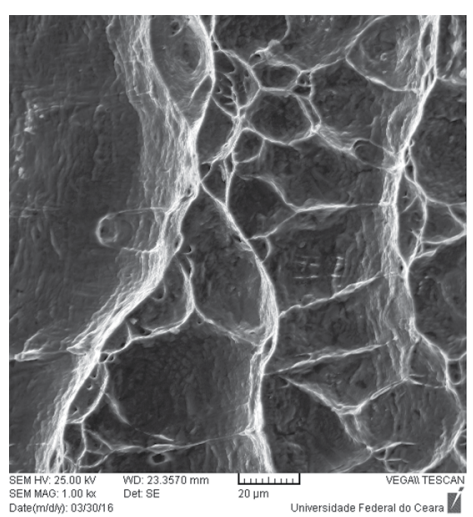

(a)

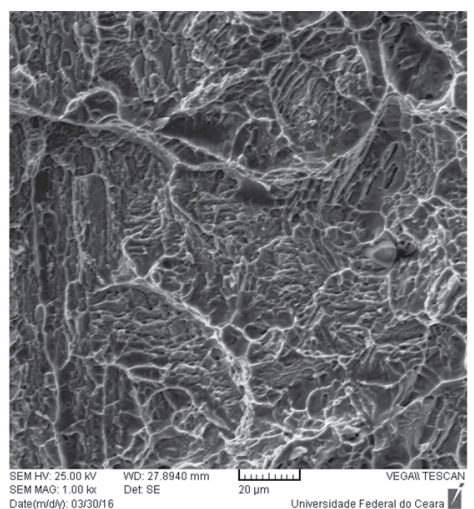

(b)

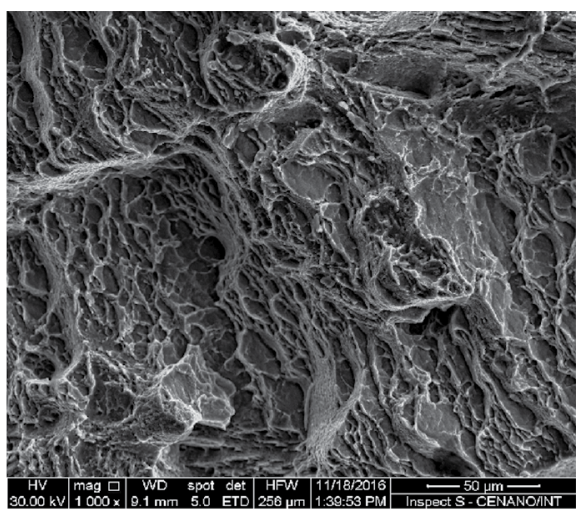

(c)

Figure 7. Surface of fracture of specimens (a) CG, (b) CG-480-3 and (c) CG-600-4 (same magnification) 